\title{
Modeling Fiscal-monetary Policy Interaction in Nigeria
}

\author{
Harrison Oluchukwu Okafor \\ Correspondence: Harrison Oluchukwu Okafor, Department of Economics, University of Ibadan, Ibadan, Nigeria
}

Received: September 22, 2012 Accepted: November 23, $2012 \quad$ Online Published: December 10, 2012

doi:10.5539/ijef.v5n1p86 URL: http://dx.doi.org/10.5539/ijef.v5n1p86

\begin{abstract}
This paper offers an analytical description of the nature of interaction between fiscal and monetary policy in Nigeria. It seeks to model how policymakers' preferences and loss functions as well as other underlying economic fundamentals and processes influence economic policy outcomes. Using a game theoretical framework, the study reveals that misalignment of policy instruments and strategies, particularly fiscal dominance over monetary policy is the major factor responsible for the ineffectiveness of economic policies in Nigeria. However, a framework that provides for an optimal threshold that synchronizes the policy preferences of the policymakers will result into an optimal solution that could improve the interaction between fiscal and monetary policy in Nigeria.
\end{abstract}

Keywords: interaction, economic fundamentals, fiscal dominance

JEL Classification: C01, C02, E60, E61, E62 and E63

\section{Introduction}

Over the last five decades, one of the key issues confronting economists and researchers is the interaction between fiscal and monetary policies. The interaction between fiscal and monetary policies as tools of economic management continues to attract research and policy attention for at least two reasons. First, the two policies and their instruments are critical in economic management of any nation or region. Second, the complementarities and conflicts of both policies have severe consequences for the stability of an economy as well as the ability to dampen business cycles (Sargent and Wallace, 1981; Dixit and Lambertini, 2001; Hannif and Arby, 2005, and Jensen and Lambertini, 2006).

Elements of mainstream economic literature relating to the interaction of fiscal and monetary policies cover issues such as the relationship between fiscal deficit financing and its consequences for monetary management and the fiscal theory of price level which shows how the monetary authorities' accommodation of fiscal expansion may precipitate or strengthen inflationary trends (Hannif and Arby, 2005 and Oyejide, 2005). Perhaps, an intriguing economic feature peculiar to most African nations particularly, countries in the sub-Saharan region is the challenge of sub-optimal interaction between fiscal and monetary policies with typifying budget deficits and its financing implications. A survey of evidence from recent studies (Note 1) reveal that the African region has been characterized by a great deal of dismal economic performance as evident in their rising inflation rates, low economic growth, rising unemployment rate, weak export base and high dependence on imports from developed and emerging market economies (Iyoha, 2003).

In some countries of Sub-Sahara Africa (SSA), particularly Nigeria and other West African nations, budget deficit has grown from low single digit levels in the 1980s to unprecedented two digit levels in the 1990 and the 2000 decades (Udo, 2007; Hefeker, 2008; and Debrun, et al., 2005). Specifically, the fluctuating nature of the country's tax base and the associated inefficiencies in the administration of tax policies are among the classical culprits accounting for these macro-imbalances.

So far, theoretical discussions about the interaction (Note 2) between fiscal and monetary policy abound but the thresholds on the conflicts of the goals, instruments, targets and coordination between them are still contentious in the literature (Sargent and Wallace, 1981; Rogolf, 1985; Pollard 1993; Mas, 1994; Dixit and Lambertini, 2001; Hannif and Arby, 2005; Oyejide, 2005 and Jensen and Lambertini, 2006). There are two main issues that often herald this policy conflict. These are the structure of the policy institutions and the credibility of the principal actors. For instance, Oyejide (2005) stress that the conflict between the authorities often arise from the conflict of objective, target as well as coordination between the two authorities. Radical central bank governors may resist the temptation to finance fiscal deficit, adjust exchange in tough times or refuse to inject liquidi g banking 
stress in order not to play into the hands of the fiscal authority. Such conflict may ty durin worsen or trigger harder economic situation as in the Peruvian case (see, Pollard 1993 and Mas, 1994).

Thus, the ability to maintain and sustain policy stance depend on the leadership structure of policy institutions. Economic Policy analysis suggests that one actor must lead and another follow. Under fiscal leadership arrangement, in other words, in the environment of fiscal dominance, monetary policy is expected to play subservient role and in most times result into sub-optimal situations (Oyejide, 2005). However, monetary policy rule or dominance depends largely on the nature of the economy and the behaviour of the fiscal policy actors' vis-à-vis the adequacy of revenue and debt sustainability level given that monetary policy may be required to play counter-cyclical role. Another possible scenario is the kind where both policy goals and outcomes are synchronized by mutual agreement or in principle committing to policy targets. These considerations shape the interaction between the fiscal and monetary policy in any economic state. Intuitively, an optimally possible threshold between the two policy institutions and goals may be required to achieve credible policy targets (Walsh, 2003).

Lack of policy credibility and transparency equally bolsters the conflict between the authorities Kyland and Prescot (1977), Barro and Gordon (1983), Rogolf (1985) and Walsh (1993 and 2003). Policymakers often renege from policy targets. For instance, monetary policy targets often time deviate in attempts to finance fiscal deficits (time inconsistency problem). Walsh (2003) show that fiscal deficit emanate from the government expenditure rising beyond the sustainable inter-temporal budget constraint (non-Ricardian Equivalent). Sargeant and Wallace (1981) argue that rising and uncontrollable budget deficits may lead quickly to inflation if economic agents expect that monetary policy will not be maintained under the burden of rising government debts. According to Warlsh (2003), deviation from monetary policy derives largely from the inability of the central bank (monetary authority) to commit to policy targets due to overbearing fiscal policy actions. From the forgoing discussion, fiscal deficit management is central in the relationship between the fiscal and monetary policy. Moreover, the interaction between fiscal and monetary policy could also be influenced by the external factors due to changes in the economic environment particularly political game among politicians and policymakers.

\section{Analytical Models}

We develop some analytical models to analyze the interaction between fiscal and monetary policy. The framework is in the spirit of Okafor (2012) which follows Blanchard and Fischer (1989) and Visser (2005). In the mainstream economic analysis, fiscal and monetary policies are two critical policy instruments required to provide policy direction in any economic state. Hence, in modeling this, we assume that there are two sectors; the fiscal and the monetary policy institutions. The fiscal authority is concerned with revenue generation and expenditure while the monetary authority is in charge of the regulation and control of money supply.

\section{Fiscal Sector}

In the fiscal sector, fiscal policy is characterized by the interplay between tax revenue, seigniorage revenues and government expenditure which is set exogenously.

\section{Revenue Function}

Government revenue function provides wedge for its constraint expenditure. The revenue function is specified in the equation below as;

$$
R=\tau_{i}+m / p
$$

Where, government generates revenue (Note 3) (Note 3) $R$, through tax $\tau_{i}$ and seigniorage revenue from money creation $m / p$. It is implied that tax revenues are insufficient hence, money is created to ensure primary budget balance (Blanchard and Fischer, 1989; Easterly, 1999 and Hefeker, 2008).

Expenditure Function

$$
E=\bar{G}
$$

Equation (2) is the total government expenditure $G$ assumed as exogenous under Keynesian hypothesis.

Balance Budget Condition

$$
R=E
$$

The balance budget condition in equation (3) may be optimal under two conditions; when government revenues and expenditures are equal and under an efficient fiscal-monetary policy interaction. However, we assumed that 
fiscal system in Nigeria is inefficient which creates distortion for monetary policy management (see, Debrun, et al. 2005). This is accounted for explicitly in the model by modifying equation 2 as;

$$
E=g_{i}+\psi_{i}
$$

Where, $\psi_{i}$ in equation (4) is the distortion in fiscal policy which increases the scope of government expenditure. This distortion is assumed to be equal with the seigniorage or money borrowed from the central bank in financing fiscal deficit as contained in equation 1 (see Debrun, et al. 2005).

$$
\psi_{i}=E-R \quad>0
$$

Equation (5) shows that government expenditure is higher than the revenue stream, which leads to fiscal deficit. This has consequences on the general price (Note 4) level as captured in equation (6).

$$
\pi=\Delta M+\psi F
$$

\section{Monetary Sector}

Theoretically, the monetary sector is characterized by the interaction between money demand and money supply in the money market. Both are influenced by some mechanisms in the market. Following Blanchard and Fischer (1989), money demand and money supply is linked as;

Money Demand Function

$$
\frac{M^{D}}{P}=\eta Y+\varphi r
$$

Equation (7) indicates that real money demand is determined by the level of income $y$ and interest rate $r$. An increase in income and a decrease in interest rate influence real money balances.

Money Supply Function

$$
M^{s}=\frac{\bar{M}^{s}}{P}
$$

Equation (8) money supply $M^{S}$ is assumed to be exogenously determined by the monetary authority.

Equilibrium Condition in the Money Market:

$$
M^{D}=M^{S} \Rightarrow \quad \frac{M^{D}}{P}=\frac{\bar{M}^{s}}{P}
$$

Equation (8) indicates that money demand and money supply are equal. More also, we assume a condition where fiscal and monetary policy interact efficiently in equation (9) can hold. However, the distortion created by the fiscal activities causes equation (8) to follow a dynamic pattern which affect equation (9). Thus, under this assumption, equation (8) can be modified to accommodate fiscal deficit as presented below.

$$
M^{S}=\frac{\bar{M}^{S}}{P}+\Psi_{i}
$$

Thus, the new equilibrium monetary condition is stated as;

$$
\frac{M^{D}}{P}=\frac{\bar{M}^{S}}{P}+\Psi_{i}
$$

Equation (11) is consistent with Blanchard and Fischer (1988) debt financing models and indicates that borrowing from central bank to finance fiscal deficit increases money supply mechanism which leads to inflation.

The parameter $\psi_{i}$ represents the degree of this distortion in monetary policy management and the source of conflict between the two policy institutions. Thus, a long-run equilibrium between the two sectors implies that;

$$
\Theta \equiv F s^{\Psi_{i}}=M s^{\Psi_{i}}=0
$$

Intuitively, the conflict between the fiscal and monetary sector emanates from the equation (12). Thus, if the central bank refuses to finance the deficit of the fiscal sector to ensure primary balance budget, policy conflict could manifest. The mechanisms for resolving such conflict could depend on the weights attach to policy makers preferences and loss functions. 


\section{Preference /Loss Function Analyses}

We assume three scenarios upon the loss functions policymakers' attach to policy preferences. The loss function of the monetary authority may be to target low inflation while the fiscal sector targets economic growth. Thus, in a case of non-synchronization of preferences as evident above, a threshold is required to ensure that optimal policy preferences are attained.

Step 1: The fiscal authority chooses a policy variable $x_{i}$, which can be government spending on goods and services or public investment, a production subsidy, or a cut in distortionary taxation; a larger $x_{i}$ means a more expansionary fiscal policy.

We assume that the fiscal authority minimizes its loss function define as;

$$
L_{i}^{F}=\frac{1}{2} \theta_{i}^{F}\left(y_{i}-y_{i}^{F}\right)^{2}+\frac{1}{2}\left(\pi-\pi_{i}^{F}\right)^{2}
$$

Where, $\left(y_{i}-y_{i}\right)^{2}$ is the weight on output gap and $\left(\pi-\pi_{i}\right)^{2}$ is the difference between actual inflation and expected inflation. Assuming further fiscal policy leadership over monetary policy implying that fiscal authority keeps its policy preference bias over monetary policy preferences; this can herald a policy conflict and disequilibrium. On the other hand, monetary policy leadership could produce similar outcome. Let us assume that the central bank chooses a similar policy variable $\pi_{o}$, such as money supply or nominal interest rate, towards controlling inflation. Higher $\pi_{o}$ means a more expansionary monetary policy. Thus, let the central bank minimizes a similar loss function;

$$
L^{M}=\frac{1}{2} \sum_{i} \theta_{i}^{M}\left(y_{i}-y_{i}^{M}\right)^{2}+\frac{1}{2}\left(\pi-\pi^{M}\right)^{2}
$$

Equation (14) is similar to equation (13) even though the policy preference and target of the monetary authority differs from the fiscal authority. Each of these scenarios has their own implications on the interaction of fiscal and monetary policy. In clearer terms, these scenarios create misalignment of policies which leads to sub-optimal solutions. However, a model that synchronizes the policy preferences of the two institutions may be desirable to develop threshold for resolving the policy preferences.

Step 2: Integrating the Policy Preferences

The overall government policy preferences cover both the fiscal and monetary policy objectives. Thus, we choose a preference function that integrates the preferences of the policymakers into a loss function. This model relates to the Dixit and Lambertini (2002) model which follows the Barro and Gordon (1983) framework and interaction between the monetary authority (central bank) and the fiscal authority. We assume that the target GDP level of the country is given as;

$$
y_{i}=\overline{y_{i}}+\sum_{i=1} a_{i} x_{i}+b_{i}\left(\pi-\pi^{e}\right), \quad i=1, \ldots, n
$$

Or in vector-matrix form;

$$
y=\bar{y}+A x+\left(\pi-\pi^{e}\right) b
$$

Similarly, the target inflation level is given by

$$
\pi=\pi_{o}+\sum_{i} a_{i} x_{i}=\pi_{o}+a^{\prime} x
$$

Where $\overline{y_{i}}$ in eqn. (15) is the natural rate of output, $a_{i}$ shows the effect of fiscal policy on the country's GDP, and $b_{i}$ is the spillover of fiscal policy on the monetary policy. These can be positive for Keynesian demand effects and negative for crowding out effects while the last term in the right hand side, $\pi^{e}$ is the inflation expected by the private sector i.e. the usual supply effect of surprise inflation $b_{i}>0$. An optimal solution for the policy preferences can be synchronized if the end goal of the policymakers as defined in eqn. (17) is achieved. 
Thus, inflation is defined as the sum of the component $\pi_{o}$ controlled by the central bank, and a contribution arising from the fiscal policies of the member countries.

\section{Step 3: Policy Outcome/Analysis}

The different policy preferences of the institutions produced sub-optimal situations. Thus, the integration of both policy preferences gives better solution. The condition under which this situation could arise is to import the law of contract proposed by Walsh (2003). This implies that each policy institution is expected to commit to the policy targets arising from the corporate (overall) government policy objectives. In other words, the fiscal and monetary authorities constitute the policymaker and would only attain a threshold of policy credibility if two conditions are met. The first condition is to set a realistic policy target in line with the aspirations of the overall national interest. Second is to ensure that policy makers are committed to policy target through rules and sanctions (Note 5).

The intuition of this reasoned analysis is derived from the broader goal of the government which is set to improve economic growth centered on price stability policy trust as contained in the Central Bank of Nigeria Autonomy Act, 2007. Thus, monetary policy should align to the fiscal policy goal and fashion out a central strategy even though the autonomous act provide for bounds for both policy institutions.

\section{Conclusion}

This paper has endeavored to analyze the interaction between fiscal and monetary policy in Nigeria. Both policies are formulated and implemented by economic agents who seek to achieve their policy goals depending on their policy preferences and loss functions. However, issues' relating to the ordering of a policymaker policy preference against the other policymaker's loss function is a veritable source of conflict between these agents. As argued in this paper, the structure of the policy institutions and the credibility of the actors as reflected in their behaviour influence the nature of their interaction. This paper summits that an optimal threshold that is able to synchronize the policy preferences of the economic agents could result into an optimal solution and improve the interaction between fiscal and monetary policy in Nigeria.

\section{References}

Barro, R. J., \& Gordon, D. B. (1983). A Positive Theory of Monetary Policy in Natural Rate Model. Journal of Political Economy, 91(4), 589-610. http://dx.doi.org/10.1086/261167

Blanchard, O. J., \& Fisher, F. (1989). Lectures on Macroeconomics. $13^{\text {th }}$ ed. MIT Press, Cambridge.

Debrun, X., Masson, P., \& Pattillo, C. (2005). Monetary Union in West Africa: Who might gain, Who Might Lose and Why? IMF Working Paper, 226, 1-35.

Dixit, A., \& Lambertini, L. (2001). Monetary and Fiscal Policy Interactions and Commitments versus Discretion in a Monetary Union. European Economic Review, 45, 977-987.

Easterly, W. (1999). Fiscal Adjustment and Macroeconomic performance in Africa. The World Bank Discussion Paper, Washinto D.C.

Hannif, M. N., \& Arby, M. F. (2005). Monetary and Fiscal Policy Coordination. Central Bank of Parkistan. Research Department Paper, Karachi.

Hefeker, Carsten. (2008). Fiscal Reform in West Africa. Journal of International Development, 22, 86-102.

Iyoha, M. A. (2003). A Common Monetary policies for West African Monetary Zone: Rationale,and design. West African Financial and Economic Review, 1(1), 1-14.

Kydland, F., \& Prescot, E. (1977). Rules rather than Discretion: the inconsistency of optimal plans. Journal of Political Economy, 85, 473-490. http://dx.doi.org/10.1086/260580

Okafor, O. H. (2012). Analysis of the Costs and Benefits of a Common Currency for the second West African Monetary Zone. A Ph.D Thesis Submitted to the Department of Economics, University of Ibadan, Nigeria.

Oyejide, T. A. (2005). Challenges of Monetary management in an environment of Fiscal dominace: Contemporary issues in the management of the Nigerian economy. In Oresekun, Ojowu and Egwaikhide (Eds), Essay in Honour of H.M.O Onitiri, NISER.

Pollard, P. S. (1993). Central Bank Independence and Economic Performance. Federal Reserve Bank of St Louis Review, 75, 21-36. 
Rogolf, Kenneth. (1985). The Optimal Degree of Commitment to an Intermediate Monetary Target. Quarterly Journal of Economics, 110, 1169-1189.

Sargent, T. J., \& Wallace, N. (1981). Some unpleasant Monetary Arithmetic. Federal Reserve Bank of Minneapolis. Quarterly Review, 5, 1-17.

Udo, E. A. (2007). Seigniorage, Revenue and Tax Smoothing in Selected Sub-saharan African Countries. Ph.D Thesis. Department of Economics, University of Ibadan, Nigeria.

Visser, H. (2005). A Guide to International Monetary Economics: Exchange rate Theories, Systems and policies. 13th ed. Edward Elgar Publishing Limited, United Kingdom.

Walsh, C. (1993). Optimal Contract for Independent Central Bankers: Private information, Performance Measures and Reappointment, Federal Reserve Bank of San Francisco, No. 02/93.

Walsh, C. (2003). Optimal Contracts for Central Bankers. American Economic Review, 85, 150-157.

Notes

Note 1. Iyoha (2003); Debrun et al., (2005) and Hefeker (2008) contain excellent review of literature

Note 2. Covers conflict of policy goals, policy preferences and target

Note 3. Tax revenue covers mainly proceeds from crude oil sales, oil license fees and personal income tax.

Note 4. Inflation in Nigeria draws from both monetary and fiscal policy actions.

Note 5. For instance, the suspension of the central bank governor or outright payment of fines in the event of violation of rules. 